\title{
LITERATURE REVIEWS OF INTERNAL ASPECTS OF INDIVIDUAL TAXPAYERS THAT INFLUENCE TAX-PAYING COMPLIANCE
}

\section{Ratna Hindria Dyah Pita Sari, Ayunita Ajengtiyas Saputri Mashuri, Annisa Azzahra}

Fakultas Ekonomi dan Bisnis Universitas Pembangunan Nasional (UPN) Veteran

Jakarta, Indonesia

Email: ratnahindria@upnvj.ac.id

\begin{abstract}
Studies on individual taxpayer compliance have been carried out. Several internal factors from within the taxpayer can affect taxpayer compliance. In this study, researchers will identify any internal factors affecting taxpayer compliance in paying taxes. Researchers reviewed 20 articles related to internal factors that can affect tax compliance. Such internal factors include tax morale, education level, income level, age, and gender. According to the 20 articles, there are still inconsistencies. Several studies have stated that these internal factors affect taxpayer compliance. Another study states that the internal factors did not affect taxpayer compliance.
\end{abstract}

Keywords: Internal Aspects; Influence; Tax-Paying Compliance

\section{Introduction}

Taxes are the primary source of the state budget for Indonesia until today. Data from the Ministry of Finance of the Republic of Indonesia shows that the realization of state revenue in 2020 is sourced chiefly from taxes, which is $65.99 \%$. Realization of other state revenues comes from customs and excise revenues of $13.13 \%$ and non-tax state revenues of $20.88 \%$. The data shows that the primary source of all state activities still comes from taxes. The tax collection system adopted in Indonesia for individual taxpayers is self-assessment.

This collection system provides confidence for taxpayers to calculate and report their tax payables. This makes it possible for taxpayers not to correctly carry out their tax obligations. In 2020, the level of formal compliance of individual employee taxpayers was $85.42 \%$. This percentage increases compared to the individual employee taxpayer compliance rate in 2019 , which was $73.2 \%$. In contrast, individual taxpayers' level of formal compliance in 2020 decreased compared to the previous year. In 2019, the level of formal compliance of non-employee individual taxpayers was $75.31 \%$, while in 2020, it decreased by 52.45\% (ddtc.co.id). According to Anjanni (2019), the success of implementing a self-assessment system can be achieved if the public has a

$\begin{array}{ll}\text { How to cite: } & \text { Sari.R.H.D.P., Ayubita Ajengtyas Saputri Mashuri \& Annisa Azzahra (2021) Literature Reviews Of } \\ & \text { Internal Aspects Of Individual Taxpayers That Influence Tax-Paying Compliance. Syntax Literate: } \\ & \text { Jurnal Ilmiah Indonesia, 6(12). http://dx.doi.org/10.36418/ Syntax-Literate.v6i12.5052 } \\ \text { E-ISSN: } & \text { 2548-1398 } \\ \text { Published by: } & \text { Ridwan Institute }\end{array}$


sufficient understanding of the applicable tax laws and regulations and understands tax reporting procedures and the tax penalties that follow.

Tax compliance may be defined as a form of exercising rights and obligations in taxation (Prassetyo \& Dicky Arisudhana, 2019). According to achieve compliance from taxpayers, it can be influenced by taxpayers' internal and external factors. The internal factors that can encourage compliance to come from inside the taxpayer. Internal factors that can encourage taxpayers to carry out their tax obligations include tax morale, education level, income level, gender, and age. For external factors, tax compliance can be achieved with a push from the external taxpayers. These external factors include the modernization of the taxation system, socialization of taxation, and applicable tax penalties.

Taxpayer compliance can be interpreted as a form of implementation of the obligations of a taxpayer. The tax collection system for individual taxpayers implemented in Indonesia is a self-assessment system. This collection system gives taxpayers the right to make calculations, payments and report taxes independently.

(Prassetyo \& Dicky Arisudhana, 2019) mentions that there are two types of tax compliance: formal tax compliance and material tax compliance. Formal tax compliance is compliance by taxpayers through fulfilling their tax obligations according to provisions of tax regulations. An example of formal tax compliance is registering as a taxpayer and submitting a tax return on time. Material tax compliance is defined as fulfilling all material tax provisions following tax laws. Examples of the material provisions are submitting a tax return honestly, completing documents that need to be attached to the tax return, and doing proper tax calculations correctly.

The theory used as the basis in this research is the Theory of Planned Behavior. This theory states that a person's behavior depends on the behavior's intention. There are three factors that encourage a person to behave, namely behavior values, normative beliefs, and control beliefs (Andreas \& Savitri, 2015). Theory of Planned Behavior is a tool that can predict individual behavior when the individual does not have complete control of his own volition.

\section{Methode}

The method used in this study is a literature review. (Snyder, 2019) stated that this method is a method of research by analyzing the views of the experts written in the research article through collecting data and the essence of the research.

Through this study, researchers try to identify previous studies relating to taxpayers' tax compliance and internal factors of taxpayers that affect the level of taxpayers' compliance. 
Table 1

Research on Individual Taxpayer Compliance and Internal Factors are Affecting It

\begin{tabular}{|c|c|c|c|c|}
\hline No & Researcher & Title & Variable & $\begin{array}{c}\text { Population \& } \\
\text { Sample } \\
\end{array}$ \\
\hline 1 & $\begin{array}{l}\text { (Tyas, } \\
\text { 2018) }\end{array}$ & $\begin{array}{l}\text { Age, Education } \\
\text { Level, Gross } \\
\text { Income, Moral } \\
\text { And Tax } \\
\text { Payment } \\
\text { Compliance }\end{array}$ & $\begin{array}{l}\text { Independent } \\
\text { Variable: Age, } \\
\text { Education, } \\
\text { Gross Income, } \\
\text { Moral } \\
\text { Dependent } \\
\text { Variable: } \\
\text { Compliance } \\
\text { with Tax } \\
\text { Payments }\end{array}$ & $\begin{array}{l}\text { The individual } \\
\text { taxpayer } \\
\text { entrepreneur in } \\
\text { Ciputra Mall. }\end{array}$ \\
\hline
\end{tabular}

2 (Lisi, 2015) $\begin{aligned} & \text { कompliance and } \\ & \text { the optimal tax } \\ & \text { policy }\end{aligned}$

Key variable and co-state variable
- Age has a positive effect on compliance with tax obligations.

- Education has a positive effect on compliance with tax obligations.

- Gross income has a positive effect on compliance with tax obligations.

- Moral has a positive effect on compliance with tax obligations

- examine the positive relationship between tax compliance and tax morale into the social welfare function and obtain optimal tax policies for honest taxpayers and those who do tax avoidance.

- Optimal tax theory pays less attention to the intrinsic influence that exists on a person, namely why people are willing to pay taxes. (Tax morale).

- The tax policy that the government must take to prevent tax evasion depends on the morality of the taxpayer.

- The participation of every citizen in defending the country is not only identified physically or in terms of physical or military training. However, it can also be realized through the role of each citizen according to their expertise, condition, and profession.

- The implementation of the 


\begin{tabular}{|c|c|c|c|c|c|}
\hline & & & & & $\begin{array}{l}\text { state defense program } \\
\text { should not be done } \\
\text { instantly. However, it must } \\
\text { also be carried out } \\
\text { continuously into a } \\
\text { sustainable program by the } \\
\text { state's financial capacity. }\end{array}$ \\
\hline 4 & $\begin{array}{c}\text { (Andreas \& } \\
\text { Savitri, } \\
2015)\end{array}$ & $\begin{array}{c}\text { The Effect of } \\
\text { Tax } \\
\text { Socialization, } \\
\text { Tax } \\
\text { Knowledge, } \\
\text { Expediency of } \\
\text { Tax ID } \\
\text { Number and } \\
\text { Service Quality } \\
\text { on Taxpayers } \\
\text { Compliance } \\
\text { With } \\
\text { Taxpayers } \\
\text { Awareness as } \\
\text { Mediating } \\
\text { Variables }\end{array}$ & $\begin{array}{l}\text { Mediating } \\
\text { Variable: } \\
\text { Taxpayer } \\
\text { Awareness }\end{array}$ & $\begin{array}{l}\text { Individual } \\
\text { taxpayers who } \\
\text { registered at } \\
\text { the tax office } \\
\text { located in } \\
\text { Pratama } \\
\text { Senapelan- } \\
\text { Pekanbaru as } \\
83.149 \\
\text { persons. }\end{array}$ & $\begin{array}{l}\text { - The tax socialization, tax } \\
\text { knowledge, and quality of } \\
\text { service were affecting tax } \\
\text { awareness. In contrast, the } \\
\text { expediency of tax id } \\
\text { numbers does not affect tax } \\
\text { awareness. } \\
\text { Tax socialization, tax } \\
\text { knowledge was affecting } \\
\text { tax compliance. In contrast, } \\
\text { the expediency of tax id } \\
\text { numbers and service quality } \\
\text { do not affect tax } \\
\text { compliance. }\end{array}$ \\
\hline 5 & $\begin{array}{l}\text { (Susila, } \\
\text { Juniult, \& } \\
\text { Hidayat, } \\
\text { 2016) }\end{array}$ & $\begin{array}{l}\text { Taxpayers and } \\
\text { Young } \\
\text { Generation: } \\
\text { Tax Morale of } \\
\text { Indonesian } \\
\text { College } \\
\text { Students }\end{array}$ & $\begin{array}{c}\text { Control } \\
\text { Variable and } \\
\text { Independent } \\
\text { Variable }\end{array}$ & $\begin{array}{l}\text { University of } \\
\text { Indonesia } \\
\text { students }\end{array}$ & $\begin{array}{l}\text { - There are different } \\
\text { responses to tax morale } \\
\text { between the female and } \\
\text { male sexes. } \\
\text { The control variables, } \\
\text { namely age, family } \\
\text { economic level, and the } \\
\text { presence or absence of } \\
\text { income itself, give the same } \\
\text { response to tax morale. } \\
\text { Moral rules give a positive } \\
\text { but not statistically } \\
\text { significant response to tax } \\
\text { morale. } \\
\text { The perception of tax } \\
\text { justice is not statistically } \\
\text { significant on tax morals. } \\
\text { The level of trust in the } \\
\text { government significantly } \\
\text { affects on tax morale. } \\
\text { Carrying out solid religious } \\
\text { education that can build } \\
\text { strong student character and } \\
\text { obey the law, including } \\
\text { being tax-abiding. } \\
\text { Taxes are considered as an } \\
\text { absolute contribution for } \\
\text { every citizen Public trust in } \\
\text { the government needs to be }\end{array}$ \\
\hline
\end{tabular}




\begin{tabular}{|c|c|c|c|c|c|}
\hline & & & & & $\begin{array}{l}\text { continuously built to } \\
\text { increase public trust in the } \\
\text { state. }\end{array}$ \\
\hline 6. & $\begin{array}{c}\text { (Cyan, } \\
\text { Koumpias, } \\
\& \\
\text { Martinez- } \\
\text { Vazquez, } \\
\text { 2016) }\end{array}$ & $\begin{array}{c}\text { The } \\
\text { determinants of } \\
\text { tax morale in } \\
\text { Pakistan }\end{array}$ & $\begin{array}{l}\text { Outcome } \\
\text { variable and } \\
\text { continuous } \\
\text { variable }\end{array}$ & $\begin{array}{c}2562 \\
\text { individuals } \\
\text { across } 13 \\
\text { metropolitan } \\
\text { areas of } \\
\text { Pakistan }\end{array}$ & $\begin{array}{l}\text { - Workers groups with lower } \\
\text { levels of employment tend } \\
\text { to have higher levels of } \\
\text { compliance. } \\
\text { The level of tax compliance } \\
\text { is very high for individuals } \\
\text { who have a very high or } \\
\text { deficient level of education } \\
\text { compared to individuals } \\
\text { who have an education } \\
\text { level equivalent to a } \\
\text { bachelor's. } \\
\text { Individuals who live in the } \\
\text { city center, who receive } \\
\text { government services, have } \\
\text { higher tax morale. } \\
\text { Women have a higher level } \\
\text { of compliance than men. }\end{array}$ \\
\hline 7 & $\begin{array}{c}\text { (Maruapey, } \\
\text { 2016) }\end{array}$ & $\begin{array}{c}\text { Tax And State } \\
\text { Defense }\end{array}$ & & & 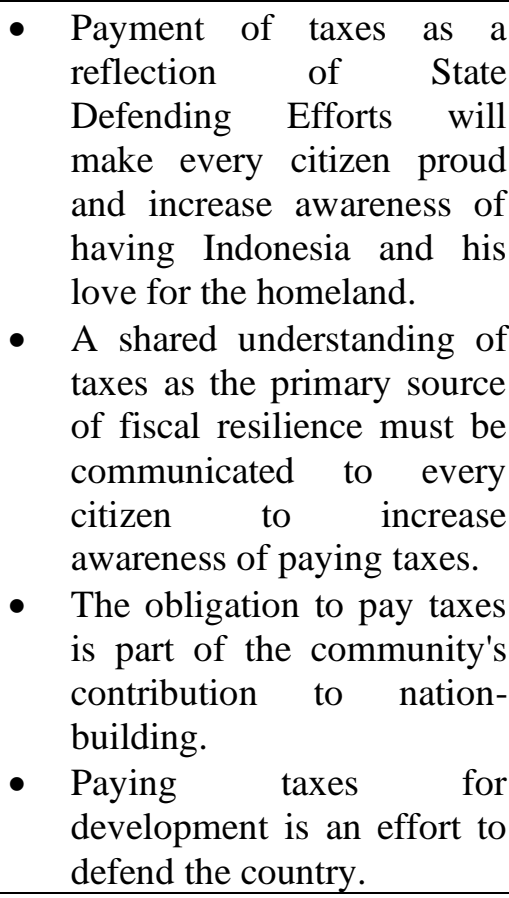 \\
\hline 8 & $\begin{array}{l}\text { (Jimenez \& } \\
\text { Iyer, 2016) }\end{array}$ & $\begin{array}{l}\text { Tax } \\
\text { compliance in a } \\
\text { social setting: } \\
\text { The influence } \\
\text { of social } \\
\text { norms, trust in } \\
\text { government, } \\
\text { and perceived } \\
\text { fairness on } \\
\text { taxpayer } \\
\text { compliance }\end{array}$ & $\begin{array}{l}\text { Depend } \\
\text { Variable: The } \\
\text { likelihood of a } \\
\text { taxpayer to } \\
\text { comply with } \\
\text { tax laws. }\end{array}$ & & 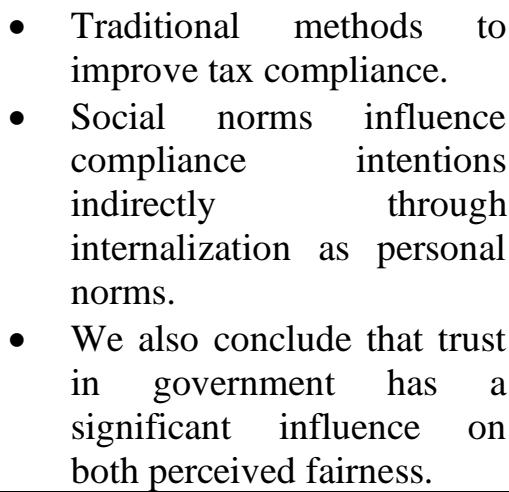 \\
\hline
\end{tabular}




\begin{tabular}{|c|c|c|c|c|c|}
\hline 9 & $\begin{array}{l}\text { (Pertiwi, } \\
\text { 2011) }\end{array}$ & $\begin{array}{l}\text { Tax Morale: } \\
\text { An Option } \\
\text { Icreasing Tax } \\
\text { Compliance Of } \\
\text { The Muslim } \\
\text { Community }\end{array}$ & $\begin{array}{l}\text { Religiosity } \\
\text { Variable \& } \\
\text { Nationalism } \\
\text { Variable }\end{array}$ & $\begin{array}{l}238 \text { individual } \\
\text { taxpayers who } \\
\text { are Muslim }\end{array}$ & $\begin{array}{l}\text { - Religiosity affects tax } \\
\text { morale. } \\
\text { Nationalism does not affect } \\
\text { tax morale. }\end{array}$ \\
\hline 10 & $\begin{array}{l}\text { (Rodriguez- } \\
\text { Justicia \& } \\
\text { Theilen, } \\
\text { 2018); } \\
\text { (Mukhadi } \\
\text { \& Madha, } \\
\text { 2018) }\end{array}$ & $\begin{array}{l}\text { Education and } \\
\text { tax morale }\end{array}$ & $\begin{array}{c}\text { Depend } \\
\text { Variable: Tax } \\
\text { morale } \\
\text { Explanatory } \\
\text { variable: } \\
\text { education }\end{array}$ & $\begin{array}{c}\text { educational } \\
\text { level }\end{array}$ & $\begin{array}{l}\text { - Individuals who get a direct } \\
\text { impact from taxes will have } \\
\text { higher tax morale. } \\
\text { The higher the level of } \\
\text { education of a person, the } \\
\text { more aware of the benefits } \\
\text { received from paying taxes. } \\
\text { The better the performance } \\
\text { of public institutions will } \\
\text { increase the individual's tax } \\
\text { morale. } \\
\text { A higher level of education } \\
\text { will have higher tax morale } \\
\text { than individuals who have a } \\
\text { low level of education. }\end{array}$ \\
\hline 11 & $\begin{array}{l}\text { (Mukhadi } \\
\text { \& Madha, } \\
\text { 2018) }\end{array}$ & & $\begin{array}{c}\text { Building State } \\
\text { Defense } \\
\text { Awareness for } \\
\text { The Millennial } \\
\text { Generation in } \\
\text { The State } \\
\text { Defense } \\
\text { System }\end{array}$ & & $\begin{array}{l}\text { - Millennials have more } \\
\text { opportunities in accessing } \\
\text { science and technology that } \\
\text { will significantly affect his } \\
\text { mindset, including in } \\
\text { responding to the } \\
\text { implementation } \\
\text { defending the country. } \\
\text { The millennial generation } \\
\text { has its way of expressing } \\
\text { defending the country. } \\
\text { Instilling awareness of } \\
\text { defending the country to the } \\
\text { millennial generation } \\
\text { adapted to its } \\
\text { characteristics. } \\
\text { The implementation of state } \\
\text { defense is adjusted to the } \\
\text { existing situation and } \\
\text { conditions to realize } \\
\text { national resilience. }\end{array}$ \\
\hline 12 & $\begin{array}{l}\text { (Wijayanto } \\
\text { J. \& } \\
\text { Marzuki, } \\
\text { 2018) }\end{array}$ & $\begin{array}{l}\text { State Defense } \\
\text { Education as a } \\
\text { Pallone of } \\
\text { Civilization of } \\
\text { the Soul of } \\
\text { Youth } \\
\text { Patriotism }\end{array}$ & & & $\begin{array}{l}\text { - The implementation of state } \\
\text { defense education is a } \\
\text { means of supporting } \\
\text { growing patriotism in } \\
\text { students. Through state } \\
\text { defense activities carried } \\
\text { out at SMA Negeri Titian } \\
\text { Teras H. Abdurrahman } \\
\text { Sayoeti Jambi, it has a role } \\
\text { as a strengthening and }\end{array}$ \\
\hline
\end{tabular}




\begin{tabular}{|c|c|c|c|c|c|}
\hline & & & & & $\begin{array}{l}\text { foundation for the spirit of } \\
\text { patriotism for students in } \\
\text { attitude or behavior. }\end{array}$ \\
\hline 13 & $\begin{array}{c}\text { (Laut \& } \\
\text { Jaya, 2019) }\end{array}$ & $\begin{array}{l}\text { The reality of } \\
\text { tax awareness } \\
\text { among the } \\
\text { younger } \\
\text { generation } \\
\text { (college } \\
\text { students) of } \\
\text { Yogyakarta } \\
\text { and Surabaya }\end{array}$ & & $\begin{array}{l}\text { - Student } \\
\text { who has } \\
\text { completed } \\
\text { five } \\
\text { semesters } \\
\text { The } \\
\text { minimum } \\
\text { value of } \\
\text { taxation } \\
\text { courses is } \\
\text { AB for } \\
\text { GPA for } \\
\text { semesters } \\
\text { one to } \\
\text { five at } \\
\text { least } 3.71 \\
\text { and above } \\
\text { Students } \\
\text { who are } \\
\text { active in } \\
\text { tax center } \\
\text { activities } \\
\text { or other } \\
\text { taxes as } \\
\text { evidenced } \\
\text { by the } \\
\text { ownership } \\
\text { of } \\
\text { certificate } \\
\text { s from } \\
\text { administra } \\
\text { tors or } \\
\text { participan } \\
\text { ts. }\end{array}$ & $\begin{array}{l}\text { - Students still do not } \\
\text { understand the meaning of } \\
\text { tax. They assume that } \\
\text { everything must have a } \\
\text { consideration }\end{array}$ \\
\hline 14 & $\begin{array}{c}\text { (Bruno, } \\
\text { 2019) }\end{array}$ & $\begin{array}{c}\text { Tax } \\
\text { enforcement, } \\
\text { tax compliance } \\
\text { and tax morale } \\
\text { in transition } \\
\text { economies: A } \\
\text { theoretical } \\
\text { model }\end{array}$ & Costs Variable & $\begin{array}{l}\text { - who argue } \\
\text { that the } \\
\text { probabilit } \\
\mathrm{y} \\
\text { distributio } \\
\mathrm{n} \text { of the } \\
\text { political } \\
\text { outcome } \\
\text { depends } \\
\text { on the } \\
\text { fraction }\end{array}$ & $\begin{array}{l}\text { - A good quality political } \\
\text { institution does not } \\
\text { guarantee that tax } \\
\text { enforcement and tax } \\
\text { compliance are also good. } \\
\text { Suppose a political } \\
\text { institution cannot attach } \\
\text { additional information. In } \\
\text { that case, it is considered } \\
\text { that the institution still has } \\
\text { low tax compliance and tax } \\
\text { morale }\end{array}$ \\
\hline 15 & $\begin{array}{l}\text { (Prassetyo } \\
\text { \& Dicky } \\
\text { Arisudhana, }\end{array}$ & $\begin{array}{l}\text { Analysis of } \\
\text { Some Aspects } \\
\text { in Taxpayers }\end{array}$ & $\begin{array}{l}\text { tax knowledge, } \\
\text { taxpayer } \\
\text { awareness, tax }\end{array}$ & $\begin{array}{l}\text { - } 100 \\
\text { responden } \\
\text { ts } \quad \text { who }\end{array}$ & $\begin{array}{l}\text { Knowledge of Taxation has } \\
\text { a positive and significant } \\
\text { effect on Taxpayer }\end{array}$ \\
\hline
\end{tabular}




\begin{tabular}{|c|c|c|c|c|c|}
\hline & 2019) & $\begin{array}{c}\text { and Tax } \\
\text { Regulations } \\
\text { that Influence } \\
\text { Taxpayer's } \\
\text { Compliance in } \\
\text { the Fulfillment } \\
\text { of its } \\
\text { Obligations }\end{array}$ & $\begin{array}{c}\text { penalty, } \\
\text { implementation } \\
\text { of e-filing on } \\
\text { taxpayer } \\
\text { compliance }\end{array}$ & $\begin{array}{l}\text { have a } \\
\text { taxpayer } \\
\text { identificat } \\
\text { ion } \\
\text { number at } \\
\text { KPP } \\
\text { Pratama } \\
\text { Jakarta } \\
\text { Kebayora } \\
\text { n Lama. }\end{array}$ & $\begin{array}{l}\text { Compliance. } \\
\text { - Awareness of paying taxes } \\
\text { has a positive and } \\
\text { significant effect on } \\
\text { taxpayer compliance. } \\
\text { - Tax Penalties do not affect } \\
\text { Taxpayer Compliance. } \\
\text { - The implementation of E- } \\
\text { Filling has a positive and } \\
\text { significant effect on } \\
\text { Taxpayer Compliance. } \\
\end{array}$ \\
\hline 16 & $\begin{array}{c}\text { (Rahayu, } \\
\text { Farida, \& } \\
\text { Apriana, } \\
\text { 2019) }\end{array}$ & $\begin{array}{c}\text { State Defense } \\
\text { Awareness in } \\
\text { Students }\end{array}$ & $\begin{array}{l}\text { love for the } \\
\text { homeland } \\
\text { variable, } \\
\text { awareness of } \\
\text { the nation and } \\
\text { the state } \\
\text { variable, belief } \\
\text { in the power of } \\
\text { Pancasila } \\
\text { variable, being } \\
\text { willing to } \\
\text { sacrifice for the } \\
\text { homeland and } \\
\text { the nation } \\
\text { variable, ability } \\
\text { to defend the } \\
\text { country } \\
\text { variable }\end{array}$ & $\begin{array}{ll}- & \text { PNJ } \\
& \text { Students }\end{array}$ & $\begin{array}{l}\text { - From the results and data } \\
\text { analysis, the highest score in } \\
\text { the student's awareness of } \\
\text { state defense is on the belief } \\
\text { in the supernatural power of } \\
\text { Pancasila, and the lowest } \\
\text { value is love for the } \\
\text { homeland variable. }\end{array}$ \\
\hline 17 & $\begin{array}{l}\text { (Suriata, } \\
\text { 2019) }\end{array}$ & $\begin{array}{l}\text { Actualization } \\
\text { of State } \\
\text { Defense } \\
\text { Awareness for } \\
\text { the Young } \\
\text { Generation in } \\
\text { Improving } \\
\text { National } \\
\text { Defense }\end{array}$ & & $\begin{array}{l}\text { - searching } \\
\text { on the } \\
\text { internet } \\
\text { for the } \\
\text { involveme } \\
\text { nt of } \\
\text { young } \\
\text { generation } \\
\text { in } \\
\text { violating } \\
\text { the law }\end{array}$ & $\begin{array}{l}\text { - Awareness of State Defense } \\
\text { in the younger generation is } \\
\text { getting weaker. } \\
\text { Awareness of defending the } \\
\text { country has not become a } \\
\text { culture in everyday life. } \\
\text { - Actualization of state } \\
\text { defense awareness which is } \\
\text { still not maximally } \\
\text { implemented }\end{array}$ \\
\hline 18 & $\begin{array}{c}\text { (Kemme, } \\
\text { Parikh, \& } \\
\text { Steigner, } \\
\text { 2020) }\end{array}$ & $\begin{array}{l}\text { Tax Morale } \\
\text { and } \\
\text { International } \\
\text { Tax Evasion }\end{array}$ & $\begin{array}{l}\text { Dependent } \\
\text { variable: Log } \\
\text { (Equity Flows) } \\
\text { Independent } \\
\text { variable: Tax } \\
\text { Savings }\end{array}$ & $\begin{array}{l}7451 \\
\text { observatio } \\
\text { ns of FPI } \\
\text { from } 138 \\
\text { source } \\
\text { countries } \\
\text { into } 21 \\
\text { OECD } \\
\text { host } \\
\text { countries } \\
\text { between } \\
2002 \text { and }\end{array}$ & $\begin{array}{l}\text { Tax avoidance at the inter- } \\
\text { country level carried out by } \\
\text { individuals is strongly } \\
\text { influenced by the individual's } \\
\text { behavior in his willingness to } \\
\text { pay or not. The author also } \\
\text { mentions that the Foreign } \\
\text { Account Tax Compliance Act } \\
\text { (FACTA) can be one way to } \\
\text { improve behavior to pay taxes. }\end{array}$ \\
\hline
\end{tabular}




\begin{tabular}{|c|c|c|c|c|c|}
\hline & & & & 2013 & \\
\hline 19 & $\begin{array}{c}\text { (Putro \& } \\
\text { Tjen, 2020) }\end{array}$ & $\begin{array}{c}\text { Analysis of } \\
\text { Tax Education } \\
\text { and Tax } \\
\text { Knowledge: } \\
\text { Survey on } \\
\text { University } \\
\text { Students in } \\
\text { Indonesia }\end{array}$ & $\begin{array}{c}\text { Variable } \\
\text { descriptions: } \\
\text { SCORE, } \\
\text { PIMP, } \\
\text { PNEED, EDU, } \\
\text { GEN, REG }\end{array}$ & $\begin{array}{l}\text { university } \\
\text { students } \\
\text { located in } \\
\text { Indonesia. }\end{array}$ & $\begin{array}{l}\text { - The DGT said that } \\
\text { knowledge of public tax in } \\
\text { Indonesia is still low. } \\
\text { There is a significant } \\
\text { difference between students } \\
\text { who have received tax } \\
\text { education and students who } \\
\text { have not received tax } \\
\text { education, in terms of their } \\
\text { level of tax knowledge. } \\
\text { Regarding students } \\
\text { perceptions regarding the } \\
\text { importance of tax education, } \\
\text { there is no significant } \\
\text { difference among students } \\
\text { who have received tax } \\
\text { education and those who } \\
\text { have not received tax } \\
\text { education. }\end{array}$ \\
\hline 20 & $\begin{array}{l}\text { (Engel, } \\
\text { Mittone, \& } \\
\text { Morreale, } \\
\text { 2020) }\end{array}$ & $\begin{array}{l}\text { Tax morale and } \\
\text { fairness in } \\
\text { conflict an } \\
\text { experiment }\end{array}$ & $\begin{array}{l}\text { the ratio of } \\
\text { declared over } \\
\text { requested tax }\end{array}$ & $\begin{array}{l}\text { participants } \\
\text { with low } \\
\text { income } \\
\text { - comply } \\
\text { less as } \\
\text { soon as } \\
\text { they are } \\
\text { made } \\
\text { aware of } \\
\text { the } \\
\text { heterogen } \\
\text { eity }\end{array}$ & $\begin{array}{l}\text { People do tax compliance } \\
\text { because of tax morale, } \\
\text { mainly because they follow } \\
\text { the rules. } \\
\text { - Taxpayers pay taxes because } \\
\text { they only have to do it. } \\
\text { - Compliance will be reduced } \\
\text { for taxpayers who have } \\
\text { multiple sources of income } \\
\text { compared to taxpayers who } \\
\text { have one source of income }\end{array}$ \\
\hline
\end{tabular}

\section{Results and Discussions}

(Cahyonowati, 2011) states that tax morale is an intrinsic driver for taxpayers in carrying out their tax obligations. Tax morale on each taxpayer can prevent the desire of each taxpayer from violating the rules (Hidayat \& Nugroho, 2010). Tax morale is always associated with domestic tax avoidance. Citizens who have low tax morale tend to do tax evasion. This tax avoidance can occur because most citizens consider it a natural thing to avoid tax (Kemme et al., 2020). The moral level of Indonesian citizens' taxes, driven by intrinsic factors, is still low, in contrast to external factors, namely hard/coercive regulations. Citizens are willing to carry out their tax obligations because of compulsion and fear of being subject to tax sanctions. Tax morale can not only affect taxpayer compliance. This tax morale can also evaluate how the taxation system is implemented in a country (Braithwaite \& Ahmed, 2005).

The taxpayer's background can also affect taxpayer compliance in carrying out their tax obligations. (Rodriguez-Justicia \& Theilen, 2018) states that the level of 
education influences each individual to comply with the obligation to pay taxes. Taxpayers who have a high educational background have a more extraordinary ability to justify the quality of government institutions' services. Taxpayers who have a high education can also assess the indirect benefits obtained when paying taxes. Tax education is also crucial for potential taxpayers to be a provision in carrying out their tax obligations in the future. This tax education will be a reference and literacy material when carrying out tax obligations (Palil, Akir, \& Ahmad, 2013).

Other factors supporting taxpayer compliance include income level, age, and gender. (Tyas, 2018) states that the gross income level of a taxpayer has a positive influence on taxpayer compliance. In addition, the age of a taxpayer also has a positive influence on taxpayer compliance. (Cyan et al., 2016) examined the effect of gender on the level of taxpayer compliance. The study results indicate that women are more obedient in carrying out their tax obligations. The study results are in line with the research of (Lasmana \& Tjaraka, 2011).

\section{Conclusions}

Until now, the source of income for the Indonesian state is still from taxes. The taxation system used in Indonesia uses many self-assessment systems. This opens up opportunities for tax evasion by taxpayers. As a result, the state income level is not optimally received following the number of taxpayers obliged to pay taxes. Several internal factors from within the taxpayer can affect taxpayer compliance. These internal factors include tax morale, income level, education level, age, and gender. This needs special attention for the government to optimize state revenues from taxes. 


\section{BIBLIOGRAFI}

Andreas, \& Savitri, Enni. (2015). The Effect of Tax Socialization, Tax Knowledge, Expediency of Tax ID Number and Service Quality on Taxpayers Compliance with Taxpayers Awareness as Mediating Variables. Procedia - Social and Behavioral Sciences, 211(September), 163-169. Google Scholar

Braithwaite, Valerie, \& Ahmed, Eliza. (2005). A threat to tax morale: The case of Australian higher education policy. Journal of Economic Psychology, 26(4), 523540. Google Scholar

Bruno, Randolph Luca. (2019). Tax enforcement, tax compliance and tax morale in transition economies: A theoretical model. European Journal of Political Economy, 56(September 2018), 193-211. Google Scholar

Cahyonowati, Nur. (2011). Model moral dan kepatuhan perpajakan: wajib pajak orang pribadi. Jurnal Akuntansi Dan Auditing Indonesia, 15(2), 161-177. Google Scholar

Cyan, Musharraf R., Koumpias, Antonios M., \& Martinez-Vazquez, Jorge. (2016). The determinants of tax morale in Pakistan. Journal of Asian Economics, 47, 23-34. Google Scholar

Engel, Christoph, Mittone, Luigi, \& Morreale, Azzurra. (2020). Tax morale and fairness in conflict an experiment. Journal of Economic Psychology, 81(August), 102314. Google Scholar

Hidayat, Widi, \& Nugroho, Argo Adhi. (2010). Studi empiris theory of planned behavior dan pengaruh kewajiban moral pada perilaku ketidakpatuhan pajak wajib pajak orang pribadi. Jurnal Akuntansi Dan Keuangan, 12(2), 82-93. Google Scholar

Jimenez, Peggy, \& Iyer, Govind S. (2016). Tax compliance in a social setting: The influence of social norms, trust in government, and perceived fairness on taxpayer compliance. Advances in Accounting, 34, 17-26. Google Scholar

Kemme, David M., Parikh, Bhavik, \& Steigner, Tanja. (2020). Tax Morale and International Tax Evasion. Journal of World Business, 55(3), 101052. Google Scholar

Lasmana, Mienati Somya, \& Tjaraka, Heru. (2011). Pengaruh Moderasi Sosio Demografi Terhadap Hubungan Antara Moral-Etika Pajak Dan Tax Avoidance Pajak Penghasilan Wajib Pajak Badan di KPP Surabaya. Jurnal Ekonomi Dan Bisnis Airlangga, 21(2). Google Scholar

Laut, I. Made, \& Jaya, Mertha. (2019). Realita Kesadaran Pajak di Kalangan Generasi Muda ( Mahasiswa ) Yogyakarta dan Surabaya I Made Laut Mertha Jaya. Jurnal Ilmiah Akuntansi, 4(2), 161-183. Google Scholar 
Ratna Hindria Dyah Pita Sari, Ayunita Ajengtiyas Saputri Mashuri, Annisa Azzahra

Lisi, Gaetano. (2015). Tax morale, tax compliance and the optimal tax policy. Economic Analysis and Policy, 45, 27-32. Google Scholar

Maruapey, M. Husein. (2016). Pajak Dan Bela Negara. Ilmu Politik Dan Komunikasi, VI No. 1(1), 2-8. Google Scholar

Mukhadi, \& Madha, Komala R. (2018). Membangun Kesadaran Bela Negara Bagi Generasi Milenial Dalam Sistem Pertahanan Negara. Manajemen Pertahanan, 4(2), 64-83. Google Scholar

Palil, Mohd Rizal, Akir, M. R., \& Ahmad, WFBW. (2013). The perception of tax payers on tax knowledge and tax education with level of tax compliance: A study the influences of religiosity. ASEAN Journal of Economics, Management and Accounting, 1(1), 118-129. Google Scholar

Pertiwi, Imanda Firmantyas Putri. (2011). Moral Pajak: Sebuah Opsi Peningkatan Kepatuhan Pajak Masyarakat Muslim. Jurnal Al -Qardh, 15, 161-177. Google Scholar

Prassetyo, Dwi, \& Dicky Arisudhana. (2019). Analisis Beberapa Aspek Dalam Diri Wajib Pajak Dan Regulasi Perpajakan Yang Mempengaruhi Ketataan Wajib Pajak Dalam Pemenuhan Kewajibannya. Jurnal Akuntansi Dan Keuangan, 8(No. 1), 88103. Google Scholar

Putro, Bernardus Bayu Ryanto Prakoso, \& Tjen, Christine. (2020). Analysis of Tax Education and Tax Knowledge: Survvey on University Student in Indonesia. Journal of the Australasian Tax Teachers Association, 15(1), 232-250. Google Scholar

Rahayu, Minto, Farida, Rita, \& Apriana, Asep. (2019). Kesadaran Bela Negara Pada Mahasiswa. Epigram, 16(2), 175-180. Google Scholar

Rahman, Zaqiu. (2015). Program Bela Negara Sebagai Perwujudan Hak dan Kewajiban Warga Negara Dalam Penyelenggaraan Pertahanan Negara. RechtsVinding, 10, 1-9. Google Scholar

Rodriguez-Justicia, David, \& Theilen, Bernd. (2018). Education and tax morale. Journal of Economic Psychology, 64, 18-48. Google Scholar

Snyder, Hannah. (2019). Literature review as a research methodology: An overview and guidelines. Journal of Business Research, 104, 333-339. Google Scholar

Suriata, I. Nengah. (2019). Aktualisasi Kesadaran Bela Negara Bagi Generasi Muda Dalam Meningkatkan Ketahanan Nasional. Jurnal Administrasi Publik, 4(1), 4756. Google Scholar

Susila, Budi, Juniult, Partomuan T., \& Hidayat, Asrul. (2016). Wajib Pajak dan Generasi Muda: Tax Morale Mahasiswa di Indonesia. Jurnal Ekonomi Dan 
Literature Reviews of Internal Aspects of Individual Taxpayers That Influence TaxPaying Compliance

Pembangunan Indonesia, 16(2), 154. Google Scholar

Tyas, Isthi Wahyuning. (2018). Umur, Tingkat Pendidikan, Penghasilan Bruto, Moral Dan Kepatuhan Pembayaran Pajak. Liquidity, 4(2), 116-125. Google Scholar

Wijayanto J., Rahmat, \& Marzuki, Marzuki. (2018). Pendidikan Bela Negara Sebagai Tonggak Peradaban Jiwa Patriotisme Generasi Muda. Jurnal Ilmiah Pendidikan Pancasila Dan Kewarganegaraan, 3(2), 186. Google Scholar

\section{Copyright holder:}

Ratna Hindria Dyah Pita Sari, Ayunita Ajengtiyas Saputri Mashuri, Annisa Azzahra (2021)

First publication right:

Syntax Literate: Jurnal Ilmiah Indonesia

This article is licensed under:

(cc) (i) (?) 